\title{
Empirical analysis of intellectual capital, potential absorptive capacity, realized absorptive capacity and cultural intelligence on innovation
}

\author{
Wisnu Yuwono ${ }^{a^{*}}$
}

${ }^{a}$ Universitas Internasional Batam, Indonesia

C H R O N I C L E

Article history:

Received: July 10, 2020

Received in revised format:

October 182020

Accepted: October 25, 2020

Available online:

October 25, 2020

Keywords:

Innovation

Intellectual capital

Potential absorptive capacity

Realized absorptive capacity

Cultural intelligence

\section{A B S T R A C T}

The purpose of this research is to reveal the influence of intellectual capital, potential absorptive capacity, realized absorptive capacity, and cultural intelligence on innovation in the tourism sector in Batam City. Batam has geopolitical and geographic advantages, located in the Malacca Strait, adjacent to and directly facing Singapore and Malaysia. It has not been optimal in exploring the potential for innovation in the tourism sector. Thus, this sector does not yet have a significant contribution to economic development. The research was conducted on the management of companies that are members of the Association of the Indonesian Tours and Travel Agencies in Batam City, totaling 54 people. By using the analysis of Structural Equation Model (SEM) with SmartPLS version 3.0, the results show that 1) intellectual capital has no effect on innovation; 2) potential absorptive capacity has no effect on innovation; 3) Realized absorptive capacity has a significant positive effect on innovation, and 4) Cultural Intelligence has a significant positive effect on innovation. The results of this study will give some insight to company managers in the tourism sector for developing innovation to maintain business continuity.

(C) 2021 by the authors; licensee Growing Science, Canada

\section{Introduction}

The tourism sector in Indonesia has succeeded in creating a multiplier effects on economic growth, including creating business opportunities and providing jobs. The tourism sector is a leading priority sector for the development of "Nawa Cita" in the current government of the Republic of Indonesia. The development of the tourism sector is designed to increase the country's foreign exchange and prosper. One way of developing the tourism sector is the development of an innovation strategy through the development of tourism human resources, because Indonesia's tourism competitiveness in 2015 was at the 50th level of 141 countries in the world, with one of the pillars, namely human resources, ranked 53 in the world. Even though in 2017 Indonesia's competitiveness ranking position increased to 42 (out of 136 countries), the human resources pillar declined to 64th out of 136 countries (WEF, 2017), so that human resource development in the tourism sector innovation needs serious attention. This kind of research is rarely implemented in the tourism sector because several studies are still focused on the high-tech industrial sector (Yuwono, Daihani, \& Willy Arafah, 2020). Batam is in the busiest international shipping traffic lane in the world, with a distance of 12.5 miles $(20 \mathrm{~km})$ from Singapore, so Batam is used as an area for industry, trade, ship transfer, and tourism. As a tourist destination, Batam, which has 373 islands and 6 main bridges connecting the main islands, has the potential to become a mainstay tourist destination. Also besides, Batam City not only has the potential to hold national and international level MICE (meeting incentive convention exhibition), but also has a lot of tourism potential (SKPD Batam, 2014). Batam City nationally ranks $3^{\text {rd }}$ according to the number of foreign tourists after Bali and Jakarta, however, based on data (BPS, 2017), the growth of foreign tourists during 2015 and 2016 shows a declining growth. The number of foreign tourists in 2015 amounted to $1,443,995$, decreased to $1,432,472$, or decreased by $(-0.80 \%)$ in 2016 , likewise from $2014-2015$

* Corresponding author.

E-mail address: wisnu@uib.ac.id (W. Yuwono) 
showed a decline in growth of (-0.70\%), and growth in recent years has also been volatile (Yuwono, Daihani, \& Arafah, 2019), even though during 2011-2014 growth has always increased significantly every year with an average value of $9.74 \%$ per year (BPS, 2017). On the other hand, the occupancy rate of starred hotel rooms (room occupancy rate) in Batam City is $42.93 \%$ (BPS, 2017) which is below the national average of 54.34\% (Ayuni et al., 2017). This reflects the amount of foreign exchange that comes in or the amount of expenditure made by tourists is not optimal. Corporate innovation consists of four dimensions, namely marketing innovation, product innovation, process innovation, and organizational innovation (Cassol, Gonçalo, \& Ruas, 2016) Innovation is influenced by several factors such as intellectual capital, potential absorptive capacity (PACAP), realized absorptive capacity (RACAP) and cultural intelligence. Several previous studies still show different results. Intellectual capital has a significant positive effect on innovation because it is a source of economic-based knowledge (WU \& Sivalogathasan, 2013), resource-based knowledge (Kianto, Ritala, Spender, \& Vanhala, 2014), which describes an organization in directing its resources (Cassol et al., 2016). However, this is not significant (Yuwono et al., 2020), where this variable must first go through RACAP mediation so that it can have a significant effect on innovation. According to Limaj \& Bernroider (2017), each component of absorption capacity (PACAP and RACAP) affects innovation. PACAP directly influences innovation through feelings and the selection of creative external knowledge (Gölgeci, Swiatowiec-Szczepanska, \& Raczkowski, 2016), and the company's ability to combine old and new knowledge (Nazarpoori, 2017), but PACAP does not affect on innovation when the team's ability at this stage is still weak (Leal-Rodríguez, Roldán, Ariza-Montes, \& LealMillán, 2014). Meanwhile, the influence of cultural intelligence on innovation is still rarely studied. Cultural intelligence variables have played a moderating role in the relationship between PACAP and RACAP on innovation (Gölgeci et al., 2016), but it was found that in fact, this variable was an independent variable that directly had a significant positive effect on innovation (Yuwono et al., 2020). Some of the studies above, show different results and need to be analyzed further. Research is very interesting as material for managerial implications and theory development, especially innovation in the tourism industry sector, This study will analyze:

\author{
a. The effect of intellectual capital on innovation? \\ b. The effect of potential absorptive capacity (PACAP) on \\ innovation?
}
c. The effect of realized absorptive capacity (RACAP) on innovation?
d. The influence of cultural intelligence on innovation?

\section{Literature Review}

Innovation is the creation of something new (Costa, Fernández, \& Dorrego, 2014). Innovation is divided into three dimensions, namely product innovation, process innovation, and managerial innovation (Nazarpoori, 2017). The general objective of innovation is to provide differentiation of new products and services in the market and increase customer satisfaction. Others researchers divide innovation into four dimensions, namely: marketing innovation, product innovation, process innovation, and organizational innovation. Marketing innovation relates to activities using shared resources with partners and the use of social media such as Facebook, online discussion forums, Twitter, and others. Product innovation includes developing new and existing products and using stakeholder ideas. Process innovation is related to the development of new methods through technology, and organizational innovation is related to developing strategic competencies for sustainable innovation through organizational culture by utilizing the human resources owned by the company (Cassol et al., 2016). According to the authors in this study, innovation is a dynamic process to create something new in meeting the growing goals and expectations of consumers. Intellectual capital is a company's intangible asset that forms the basis for the company in developing innovation. This intellectual capital consists of three dimensions, namely human capital, social capital, and structural capital which will affect absorption capacity, and then influence innovation (Cassol et al., 2016; Engelman et al., 2017; Nazarpoori, 2017). So that intellectual capital is related to the company's capacity to create and apply the foundations of intangible knowledge, creating value, and thus encouraging company growth and innovation. Intellectual capital is also displayed in three dimensions, namely staffing that describe human capital, structures in organizations that describe structural capital, and consumers that describe relational capital (Survilaite, Tamošiūnienè, \& Shatrevich, 2015). Intellectual capital has an impact on innovation because the company has an organizational structure that values sustainable employee development (Kalkan et al., 2014) and develops relationships between stakeholders (Kalkan et al., 2014; Maboudi et al., 2015). These are the things that encourage companies to identify improvements for product innovation, process innovation, and marketing innovation (Kalkan et al., 2014) and technological innovation (Li \& Yu, 2018). Intellectual capital contains various knowledge relevant to the organization that can be used to improve skills that drive innovation (Omoush, 2019). Intellectual capital is useful for innovation purposes because it is a knowledge-based economy (WU \& Sivalogathasan, 2013), knowledge-based resources (Kianto et al., 2014), and leads to a situation of organizational competitive development which is a very strategic source of the company. important and effective in driving innovation (Maboudi et al., 2015).

\section{$\mathrm{H}_{1}$. Intellectual capital has a positive relationship with innovation.}

The term absorption capacity was originally developed by Cohen \& Levinthal (1990) where an organization needs knowledge that is relevant to the organization and is used to increase creativity in the organization. This absorption capacity is then developed into two parts, namely potential absorptive capacity or PACAP and realized absorptive capacity or RACAP (Zahra $\&$ George, 2002). Absorption capacity is defined as the ability of employees and motivation to encourage external knowledge and the willingness of the organization to use this knowledge for company innovation (Nazarpoori, 2017). PACAP is a stage where companies get external knowledge and understand this knowledge, so PACAP is divided into two dimensions, namely acquisition and assimilation (Zahra \& George, 2002). The acquisition is a company's ability to identify and obtain external knowledge, while assimilation is a company's ability to analyze, process and interpret and understand information obtained 
from external sources (Cohen \& Levinthal, 1990; Distel, 2017; Engelman et al., 2017; Leal-Rodríguez et al., 2014; Nazarpoori, 2017; Tan, 2018). Each component of the PACAP influences innovation (Limaj \& Bernroider, 2017). The author in this study defines PACAP as the company's ability to acquire and understand knowledge relevant to the company's core business, with the dimensions of acquisition and assimilation. PACAP influences innovation by providing a flexible strategy that allows companies to change and reconfigure organizational operations (Davila, Durst, \& Varvakis, 2018), and the appropriateness of selecting relevant external knowledge (Gölgeci et al., 2016). Companies with strong PACAP can absorb the results of gathering new knowledge and combine them with previous knowledge for the innovation process (Nazarpoori, 2017), so that the organizational team ability factor greatly influences PACAP in determining the success of innovation.

$\mathrm{H}_{2}$. Potential absorptive capacity has a positive relationship with innovation.

RACAP is the company's ability to use the knowledge that has been acquired to become useful knowledge. RACAP consists of the transformation and exploitation of knowledge which includes how companies acquire new knowledge and the consequences of combining existing and new knowledge into the company's operational activities (Leal-Rodríguez et al., 2014; Zahra \& George, 2002). Transformation also means the company's ability to unify misaligned information and combine it into something new; and the exploitation dimension, namely the company's ability to improve, utilize and create skills that focus on the application of knowledge (Cohen \& Levinthal, 1990; Distel, 2017; Engelman et al., 2017; Nazarpoori, 2017; Tan, 2018) The author defines RACAP as the company's ability to utilize its knowledge as more useful and useful knowledge for organizational goals with dimensions consisting of knowledge transformation and exploitation. RACAP is the process of entering new knowledge and combining it with old knowledge into something new for organizations in the form of innovation. RACAP can directly influence innovation because the digestion process of external knowledge can be directly converted into direct input for innovation (Gölgeci et al., 2016). RACAP influences innovation because innovation begins with organizations that have begun to identify technology (Limaj \& Bernroider, 2017), and these organizations have a constant interest in identifying new technologies to incorporate into operational processes and products (Davila et al., 2018). RACAP is an important stage that drives innovation through the application of new knowledge (Gunawan et al., 2017; Nazarpoori, 2017), and employee collaboration (Mennens, Gils, Odekerken-Schröder, \& Letterie, 2018). In influencing innovation significantly, RACAP also requires control and stability in supporting these innovations (Albort-Morant et al., 2018).

$\mathrm{H}_{3}$. Realized absorptive capacity has a positive relationship with innovation.

Cultural intelligence is a dynamic ability to ward off cultural differences that hinder knowledge exploration and transfer within organizations. The dimensions of this variable include metacognitive (knowledge and control of cognition, planning, monitoring, and revision of mental models); cognitive (knowledge structure, alertness, pattern recognition, and selfawareness); motivation (learning, efficacy, persistence, goals, enrichment, and values); and behavior (set of habits) (Ang et al., 2007; Gölgeci et al., 2016). In this study, the authors define the cultural intelligence variable as the ability of an organization to adapt to various cultures so that interactions between parts of the organization can run as it should. The dimensions of this variable are metacognitive intelligence, cognitive, motivation, and behavior. Cultural intelligence has a significant direct influence on innovation (Yuwono et al., 2020). Because this variable functions to adjust the culture in the organization to help accelerate the innovation process. Cultural intelligence is developed and practiced by individuals and collected at the company level through structural behavior and means in response to external demands so that in the current era of globalization, its role will greatly help in increasing the interaction and interdependence between culturally different social and political entities (Ang et al., 2007).

$\mathrm{H}_{4}$. Cultural intelligence has a positive relationship with innovation.

The conceptual framework created is shown in the image below:

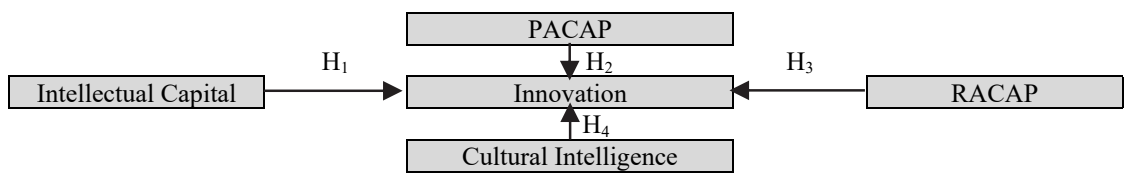

\section{Method}

Fig. 1. Research model

This research is quantitative research with a descriptive analysis approach to describe, provide a factual and accurate picture of the practice of implementing innovation in the tourism sector in Batam City using survey techniques. The dependent variable in this study is innovation with the dimensions of marketing innovation, product innovation, process innovation, and organizational innovation (Cassol et al., 2016), while the independent variables include intellectual capital variables with dimensions of human capital, social capital, and structural capital (Costa et al., 2014; Engelman et al., 2017), PACAP variables with dimensions of acquisition and assimilation, RACAP variables with dimensions of transformation and exploitation (Engelman et al., 2017), cultural intelligence variables with dimensions of metacognitive intelligence, cognitive, motivation and behavior (Ang et al., 2007; Gölgeci et al., 2016). Respondents in this study were all company managers who are members of the Association of The Indonesian Tours and Travel Agencies in Batam City, totaling 54 companies that are still active, and those that have been operating for more than three years. The data collection technique was done by distributing questionnaires which consisted of 59 statement indicators referring to the research above, then measured using a Likert scale 
of 1-5 (strongly disagree-strongly agree). The analysis technique and hypothesis testing used partial least square (PLS) with the SmartPLS version 3.0 software (Ghozali \& Latan, 2013).

\section{Findings, Discussion, and Managerial Implications}

Based on the results of data collection through distributing questionnaires to company managers who are members of the Association of The Indonesian Tours and Travel Agencies in Batam City, amounting to 70, there were 54 questionnaires returned. The descriptive statistics below describe the characteristics of the respondents as follows:

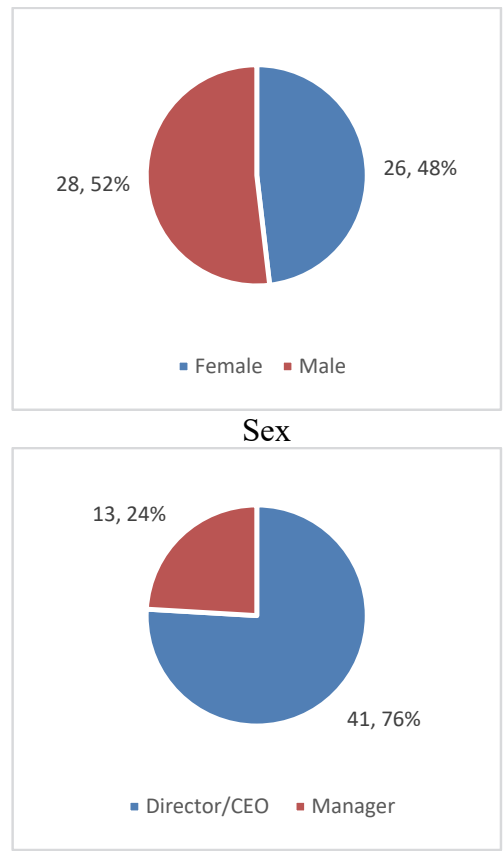

Job position

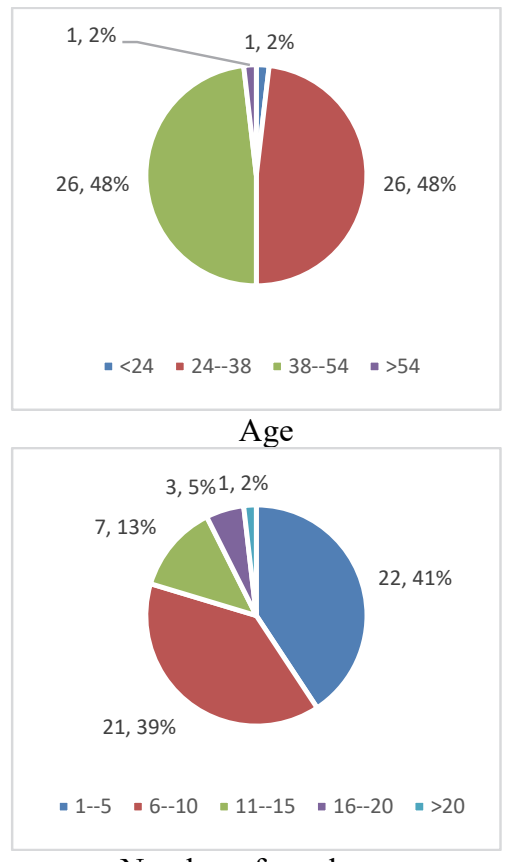

Number of employees

Fig. 2. Characteristics of the participants

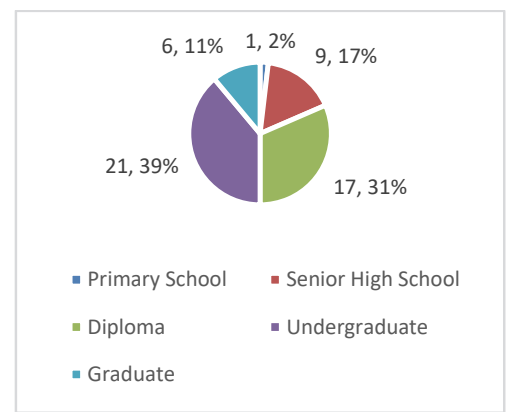

Educational background

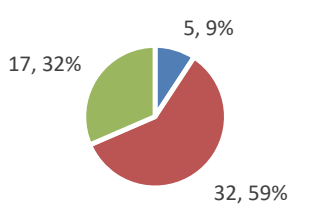

$$
\begin{aligned}
& \text { - <Rp. } 50 \text { Million } \\
& \text { - Rp. } 50 \text { million-Rp } 500 \text { Million } \\
& \text { - >Rp. } 500 \text { Million }
\end{aligned}
$$

Asset value

Based on the data above, when viewed from the company's assets and turnover, it can be concluded that the majority of respondents are SMEs with a relatively small number of workers. We measur the outer model through convergent validity testing with reflexive indicators with the SmartPLS 3.0 program. The criteria for the factor loading value is more than 0.7 (if it does not meet the criteria, it will be removed from the calculation) and the Average Variance Extracted (AVE) is above 5.0 (Ghozali \& Latan, 2013). The results of the outer model of validity testing are given in Table 1.

\begin{tabular}{|c|c|c|c|c|c|c|c|c|}
\hline Variable & Factor loading & Result & Variable & Factor loading & Result & Variable & Factor loading & Result \\
\hline Innovation & & & PACAP & & & Cultural Intelligence & & \\
\hline MRI1 & 0.898 & Valid & ACQ2 & 0.758 & Valid & MET1 & 0.831 & Valid \\
\hline MRI2 & 0.812 & Valid & ASS1 & 0.829 & Valid & MET2 & 0.881 & Valid \\
\hline PRD1 & 0.797 & Valid & ASS2 & 0.808 & Valid & MET3 & 0.895 & Valid \\
\hline PRD2 & 0.863 & Valid & ASS3 & 0.915 & Valid & COG1 & 0.818 & Valid \\
\hline PRD3 & 0.719 & Valid & ASS4 & 0.759 & Valid & COG2 & 0.893 & Valid \\
\hline PROC1 & 0.903 & Valid & RACAP & & & COG3 & 0.87 & Valid \\
\hline PROC2 & 0.882 & Valid & TRF1 & 0.779 & Valid & COG4 & 0.904 & Valid \\
\hline PROC3 & 0.843 & Valid & TRF2 & 0.774 & Valid & MOT1 & 0.881 & Valid \\
\hline ORI1 & 0.868 & Valid & TRF3 & 0.733 & Valid & MOT2 & 0.885 & Valid \\
\hline ORI2 & 0.806 & Valid & TRF4 & 0.872 & Valid & MOT3 & 0.854 & Valid \\
\hline ORI3 & 0.875 & Valid & EXP1 & 0.724 & Valid & BEH1 & 0.796 & Valid \\
\hline Intellectual Capital & & & EXP2 & 0.816 & Valid & $\mathrm{BEH} 2$ & 0.882 & Valid \\
\hline HUC1 & 0.704 & Valid & EXP2 & 0.852 & Valid & $\mathrm{BEH} 3$ & 0.744 & Valid \\
\hline HUC2 & 0.727 & Valid & & & & & \multirow{7}{*}{\multicolumn{2}{|c|}{ Source: Primary Data Processed, 2020}} \\
\hline SOC1 & 0.765 & Valid & & & & & & \\
\hline SOC2 & 0.781 & Valid & & & & & & \\
\hline STC1 & 0.787 & Valid & & & & & & \\
\hline STC7 & 0.791 & Valid & & & & & & \\
\hline STC8 & 0.763 & Valid & & & & & & \\
\hline STC11 & 0.764 & Valid & & & & & & \\
\hline
\end{tabular}

Table 1

Validity test 
Testing the outer model is also carried out by means of reliability testing. Reliability is used to test the reliability of a construct to prove the accuracy, consistency, and accuracy of the instrument in construct measurement. Through the SmartPLS 3.0 program, measuring reliability is done in two ways, namely by Cronbach's alpha and composite reliability. The value of Cronbach's alpha and composite reliability must be more than 0.7 to meet the reliability requirements (Ghozali \& Latan, 2013). The calculation results can be seen in Table 3 as follows,

Table 2

Test of Convergent Validity by AVE

\begin{tabular}{lcr}
\hline Variable & $\begin{array}{c}\text { Average Variable Ex- } \\
\text { tracted }(\text { AVE) }\end{array}$ & Result \\
\hline Innovation & 0.713 & Valid \\
Intellectual & 0.735 & Valid \\
PACAP & 0.666 & Valid \\
RACAP & 0.631 & Valid \\
Cultural Intelligence & 0.735 & Valid \\
\hline \multicolumn{4}{r}{ Source: Primary Data Processed, 2020 }
\end{tabular}

Table 3

Reliability Test

\begin{tabular}{llll}
\hline Variable & Cronbach's Alpha & Composite Reliability & Result \\
\hline Innovation & 0.959 & 0.965 & Reliable \\
Intellectual Capital & 0.896 & 0.917 & Reliable \\
PACAP & 0.874 & 0.908 & Reliable \\
RACAP & 0.902 & 0.923 & Reliable \\
Cultural Intelligence & 0.970 & 0.973 & Reliable \\
\hline
\end{tabular}

The intellectual capital variable does not have a significant effect on innovation. The effect of intellectual capital on innovation is positive but not significant, which means that the greater the value of intellectual capital has no significant effect on increasing the value of innovation. In the tourism sector in Batam actually, the majority of respondents have a bachelor's degree or diploma education who have sufficient basic knowledge in the tourism sector, but because the majority of companies only have limited human resources, namely 1-5 people (40\%) and 6-10 (38\%) per company, the organizational structure and employee rewards on an ongoing basis are not optimal. For several reasons, companies employ few employees such as business efficiency, which makes it possible to have multiple jobs or over-job descriptions of each employee. Intellectual capital, which consists of human capital, social capital, and structural capital, which is owned by the company, is ultimately unable to develop adequate skills in encouraging innovation. Fig. 3 and Table 4 show the results of our survey.

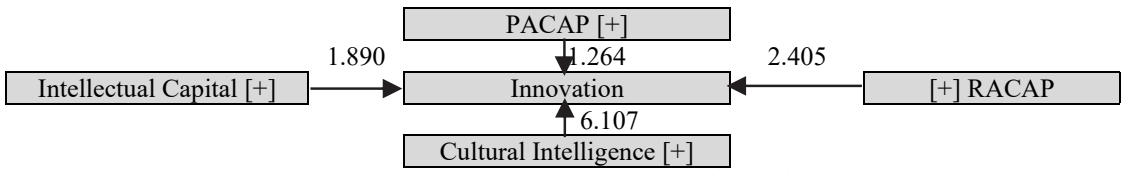

Fig. 3. The results of testing the hypotheses

Table 4

Hypothesis Test

\begin{tabular}{|c|c|c|c|c|}
\hline Hypothesis & Description & T-Statistic & P-Value & Conclusion \\
\hline 1 & Intellectual capital has a significant positive effect on innovation & 1.890 & 0.059 & Rejected \\
\hline 2 & PACAP has a significant positive effect on innovation. & 1.264 & 0.207 & Rejected \\
\hline 3 & RACAP has a significant positive effect on innovation. & 2.405 & 0.017 & Accepted \\
\hline 4 & Cultural Intelligence has a significant positive effect on innovation & 6.107 & 0.000 & Accepted \\
\hline
\end{tabular}

The organizational structure determines the drive for corporate innovation (Kalkan et al., 2014). The condition will prevent the company from specifically identifying improvements for innovation. The results of the study are in line with research by Santoso et al. (2017), which concluded that there is a lack of direct contribution from intellectual capital to company innovation. The PACAP variable does not have a significant effect on innovation. These results contradict studies (AlbortMorant, Leal-Rodríguez, \& Marchi, 2018; Davila et al., 2018; Gölgeci et al., 2016; Limaj \& Bernroider, 2017; Nazarpoori, 2017), but supports the research of Leal-Rodríguez et al. (2014). PACAP does not affect innovation due to organizational limitations in choosing creative external knowledge to be implemented directly into useful innovations in the company. When viewed from the research data, PACAP is less strong because of its average value. The lowest PACAP rate among other research variables indicates that the company lacks filling and is less able to choose creative knowledge. Low PACAP scores reduce the ability to absorb new knowledge results and combine it with previous knowledge in driving innovation. The RACAP variable has a direct effect on the innovation variable. The influence of RACAP on innovation is positive and significant, which means that the greater the value of RACAP, the greater the value of innovation. The results of this study support the research of Davila et al. (2018); Gölgeci et al. (2016); Gunawan et al. (2017); Limaj \& Bernroider (2017). RACAP influences innovation because the digestion process of RACAP can directly be converted into innovations that will be carried out. Also besides, companies that are members of the Association of The Indonesian Tours and Travel Agencies Batam have succeeded in developing old knowledge and new knowledge so that they often produce innovative products such as attractive tour packages that allow the company to continue to grow and develop. The cultural intelligence variable has a significant positive effect on innovation. Batam is a city in Indonesia that consists of various ethnicities (Saefuloh, 2011). This condition gives rise to different habitual tendencies, for example, the use of foreign languages, expressions, accent, interaction with various cultures of the community both from Indonesia and abroad, consumption of foreign products, and other activities in the economic and socio-cultural fields (Dedees, 2016) Likewise in the world of work in the tourism sector where the elements of the cultural intelligence variable have been implemented well to increase interaction in encouraging the innovation process in the tourism sector. The results of this study support the research of (Yuwono et al., 2020). The managerial implementation 
of the results of this study is that companies always pay attention to the aspects of strengthening intellectual capital between determining the organizational structure and relationships with the most optimal stakeholders in identifying innovation improvements. In addition, it is also recommended to have a strategy for searching and developing specific talent for employees in accordance with the company's strategy, providing innovation incentives, and determining the right job descriptions, especially a division that deals with aspects of company innovation.

\section{Conclusion and scope for future research}

Based on the results of data analysis and discussion, it can be concluded that 1) $\mathrm{H}_{1}$ is rejected, intellectual capital has no effevt on innovation; 2) $\mathrm{H}_{2}$ is rejected, PACAP has no influence on innovation; 3) $\mathrm{H}_{3}$ accepted, RACAP has a significant positive effect on innovation, and 4) $\mathrm{H}_{4}$ accepted, that Cultural Intelligence has a significant positive effect on innovation. Future research is recommended to also consider various aspects, for example, the company's financial aspects, because innovation development requires financial support. Besides, the role of the government in supporting company innovation also needs to be used as a study material considering that the local government is also responsible for innovation, especially destinations in the tourism sector (Yuwono, 2018).

\section{References}

Albort-Morant, G., Henseler, J., Cepeda-Carrion, G., \& Leal-Rodriguez, A. L. (2018). Potential and realized absorptive capacity as complementary drivers of green product and process innovation performance. Sustainability, 10(381), 1-20.

Albort-Morant, G., Leal-Rodríguez, A. L., \& Marchi, V. De. (2018). Absorptive capacity and relationship learning mechanisms as complementary drivers of green innovation performance. Journal of Knowledge Management, O(0), 1-21.

Ang, S., Dyne, L. Van, Koh, C., Ng, K. Y., Templer, K. J., Tay, C., \& Chandrasekar, N. A. (2007). Cultural intelligence: Its measurement and effects on cultural judgment and decision making, cultural adaptation and task performance. Management and Organization Review, 3(3), 335-337. http://doi.org/10.1111/j-1 740-8784.2007.00082.X

Ayuni, S., Anam, C., Setiyawati, N., Riyadi, HAtuti, A., Larasaty, P., \& Pratiwi, A. I. (2017). Laporan Perekonomian Indonesia 2017. BPS.

BPS. (2017). Kota Batam dalam Angka 2017. BPS. Retrieved from https://batamkota.bps.go.id/

Cassol, A., Gonçalo, C. R., \& Ruas, R. L. (2016). Redefining the relationship between intellectual capital and innovation: The mediating role of absorptive capacity. Brazilian Administration Review, 13(4), 1-25.

Cohen, W. M., \& Levinthal, D. A. (1990). Absorptive Capacity: A New Perspective on and Innovation Learning. Administrative Science Quarterly, 35(1), 128-152. Retrieved from http://www.jstor.org/stable/2393553 .

Costa, R. V., Fernández, C. F.-J., \& Dorrego, P. F. (2014). Critical elements for product innovation at Portuguese innovative SMEs : an intellectual capital perspective. Knowledge Management Research \& Practice, 12(3), 322-338.

Davila, G. A., Durst, S., \& Varvakis, G. (2018). Knowledge absorptive capacity, innovation, and firm's performance performance: Insights from the south of Brazil. International Journal of Innovation Management, 22(2), 1-34.

Dedees, A. R. (2016). Melayu di Atas Tiga Bendera: Konstruksi Identitas Nasionalisme Masyarakat Perbatasan di Kepulauan Batam. Jurnal Ilmu Sosial Dan Ilmu Politik, 19(2), 141.

Distel, A. P. (2017). Unveiling the Microfoundations of Absorptive Capacity : A Study of Coleman 's Bathtub Model. Journal of Management, 20(10), 1-31. http://doi.org/10.1177/0149206317741963

Engelman, R. M., Fracasso, E. M., Schmidt, S., \& Zen, A. C. (2017). Intellectual capital, absorptive capacity and product innovation. Management Decision, 55(3), 474-490. http://doi.org/10.1108/MD-05-2016-0315

Ghozali, I., \& Latan, H. (2013). Partial Least Squares: Konsep, teknik dan Aplikasi Menggunakan program SmartPLS 3.0. Badan Penerbit Universitas Diponegoro Semarang.

Gölgeci, I., Swiatowiec-Szczepanska, J., \& Raczkowski, K. (2016). How does cultural intelligence influence the relationships between potential and realised absorptive capacity and innovativeness? Evidence from Poland. Technology Analysis \& Strategic Management, O(0), 1-15. http://doi.org/10.1080/09537325.2016.1245858

Gunawan, W., Gerardus, P., Tji, B. J., \& Richard, K. (2017). The Use of Absorptive Capacity in Improving the New Product Development (NPD). In International Conference on Computing and Applied Informatics 2016 (pp. 1-10). http://doi.org/10.1088/1742-6596/755/1/011001

Kalkan, A., Bozkurt, Ö. Ç., \& Arman, M. (2014). The Impacts of Intellectual Capital, Innovation and Organizational Strategy on Firm Performance. Procedia - Social and Behavioral Sciences, 150, 700-707.

Kianto, A., Ritala, P., Spender, J. C., \& Vanhala, M. (2014). The interaction of intellectual capital assets and knowledge management practices in organizational value creation. Journal of Intellectual Capital, 15(3), 362-375.

Leal-Rodríguez, A. L., Roldán, J. L., Ariza-Montes, J. A., \& Leal-Millán, A. (2014). From potential absorptive capacity to innovation outcomes in project teams: The conditional mediating role of the realized absorptive capacity in a relational learning context. International Journal of Project Management, 32(6), 894-907.

Li, J., \& Yu, D. (2018). The path to innovation: The antecedent perspective of intellectual capital and organizational character. Frontiers in Psychology, 9(DEC), 1-18. http://doi.org/10.3389/fpsyg.2018.02445

Limaj, E., \& Bernroider, E. W. (2019). The roles of absorptive capacity and cultural balance for exploratory and exploitative innovation in SMEs. Journal of Business Research, 94, 137-153.

Maboudi, M., Mobaraki, M. H., \& Khavandkar, J. (2015). The effect of intellectual capital on innovation: A case study of an 
institute for advanced studies in basic sciences located in the science and technology Park of Zanjan. Journal of Entrepreneurship \& Organization Management, 04(03). http://doi.org/10.4172/2169-026x.1000148

Mennens, K., Gils, A. Van, Odekerken-Schröder, G., \& Letterie, W. (2018). Exploring antecedents of service innovation performance in manufacturing SMEs. International Small Business Journal: Researching Entrepreneurship, 00(0), 1-21. http://doi.org/10.1177/0266242617749687

Nazarpoori, A. H. (2017). Survey the effects of intellectual capital and absorptive capacity on innovation capability (Case Study of Saipa Company in Tehran). International Journal of Innovation Management, 21(2), 1-19.

Omoush, M. M. (2019). Impact of intangible assets (Intellectual Capital, Knowledge Management) on innovation: A study on tourist agencies in Jordan (Tourist Agencies in Irbid). International Journal of Business and Management, 14(6), 138.

Saefuloh, A. A. (2011). Kebijakan Ketenagakerjaan pada Sektor Industri di Kota Batam. Kajian, 16(1), 189-217. Retrieved from https://jurnal.dpr.go.id/index.php/kajian/article/view/522

Santoso, S. I., Djaelani, Y., \& Destryanti. (2017). Pengaruh Intellectual Capital Terhadap Pertumbuhan, Nilai Pasar, Produktivitas Dan Profitabilitas. Jurnal Ilmiah Akuntansi Peradaban, Vol. III(2), 85-113.

SKPD Batam. (2014). Obyek Wisata. SKPD $\quad$ Batam. Retrieved from https://arsipskpd.batam.go.id/batamkota/skpd.batamkota.go.id/pariwisata/objek -wisata-batam/index.html

Survilaitè, S., Tamošiūnienè, R., \& Shatrevich, V. (2015). Intellectual Capital Approach to Modern Management through the Perspective of a Company's Value Added. Verslas: Teorija Ir prakTika / Business: Theory and pracTice, 16(1), $31-44$.

Tan, A. (2018). The effect of social capital and absorptive capacity through knowledge management on finance company performance in Indonesia. International Business Research, 11(1), 87-101. http://doi.org/10.5539/ibr.v11n1p87

WEF. (2017). The Travel \& Tourism Competitiveness Report 2017. Retrieved from https://www.weforum.org/reports/thetravel-tourism-competitiveness-report-2017

WU, X., \& Sivalogathasan, V. (2013). Innovation capability for better performance: Intellectual capital and organization performance of the apparel industry in Sri Lanka. Journal of Advanced Management Science, 1(3), $273-277$.

Yuwono, W. (2018). Perancangan model framework manajemen strategik planning sektor pariwisata di Provinsi Kepulauan Riau. Journal of Accounting \& Management Innovation, 2(1), 14-25. Retrieved from https://ejournal.medan.uph.edu/index.php/jam/article/view/169/51

Yuwono, W., Daihani, D. U., \& Arafah, W. (2019). The Effect Of Intellectual Capital And Potential Absorptive Capacity To The Realized Absoptive Capacity Of Tourism Service Industry. SSRG International Journal of Economics and Management Studies (SSRG-IJEMS) (Vol. 6). http://doi.org/10.14445/23939125/ijems-v6i5p115

Yuwono, W., Daihani, D. U., \& Willy Arafah. (2020). Empirical testing of the mediating effect of absorptive capacity and moderation of cultural intelligence on intellectual capital and innovation analysis on the tourism industry. Advances in Economics, Business and Management Research - Proceedings of the International Conference on Management, Accounting, and Economy (ICMAE 2020), 151(-), 243-247. http://doi.org/https://doi.org/10.2991/aebmr.k.200915.056

Zahra, S. A., \& George, G. (2002). Absorptive capacity: A review reconceptualization, and extension. Academy of Management, 27(2), 185-203. Retrieved from http://www.jstor.org/stable/4134351

\section{Appendix}

The questionnaire used for the proposed study of this paper.

\begin{tabular}{|c|c|c|c|c|c|c|}
\hline Code & Statement Questionnaire & 1 & 2 & 3 & 4 & 5 \\
\hline & $\begin{array}{l}\text { Innovation (Cassol et al., 2016) } \\
\text { Marketing Innovation }\end{array}$ & & & & & \\
\hline MRI1 & The company uses partner firms', financial and technological human resources to develop its portfolio of innovative projects. & & & & & \\
\hline MRI2 & $\begin{array}{l}\text { The company monitors social networks and uses formal and informal social networks, such as blogs, discussion forums, Twitter, } \\
\text { Facebook, Orkut and other media to monitor and evaluate the impact of launching its innovations } \\
\text { Product Innovation }\end{array}$ & & & & & \\
\hline PRD1 & The company develops new products. & & & & & \\
\hline PRD2 & The company develops improvements to existing products. & & & & & \\
\hline \multirow[t]{2}{*}{ PRD3 } & The company has created or improved products using employees, customers or suppliers' ideas. & & & & & \\
\hline & Process Innovation & & & & & \\
\hline PROC1 & The company develops new production methods. & & & & & \\
\hline PROC2 & The company is improving its current production methods. & & & & & \\
\hline \multirow[t]{2}{*}{ PROC3 } & The company seeks to apply new technologies in its production systems. & & & & & \\
\hline & Organizational Innovation & & & & & \\
\hline ORI1 & $\begin{array}{l}\text { The company develops strategic competencies for innovation aiming for sustainability of its business and future competitive } \\
\text { advantage. }\end{array}$ & & & & & \\
\hline ORI2 & The company promotes an innovation-oriented organizational culture. & & & & & \\
\hline \multirow[t]{2}{*}{ ORI3 } & The company encourages employees to take initiative and behave innovatively in all of its different units/areas/departments & & & & & \\
\hline & $\begin{array}{l}\text { Intellectual Capital } \\
\text { Human capital (Engelman et al., 2017) }\end{array}$ & & & & & \\
\hline HUC1 & Our employees are highly skilled. & & & & & \\
\hline HUC2 & Our employees are widely considered the best in our industry. & & & & & \\
\hline HUC3 & Our employees are creative and bright. & & & & & \\
\hline HUC4 & Our employees are experts in their particular jobs and functions. & & & & & \\
\hline HUC5 & Our employees develop new ideas and knowledge. & & & & & \\
\hline
\end{tabular}




\begin{tabular}{|c|c|}
\hline & Social capital (Engelman et al., 2017) \\
\hline SOC1 & Our employees are skilled at collaborating with each other to diagnose and solve problems. \\
\hline $\mathrm{SOC} 2$ & Our employees share information and learn from one another. \\
\hline $\mathrm{SOC} 3$ & Our employees interact and exchange ideas with people from different areas of the company. \\
\hline SOC4 & $\begin{array}{l}\text { Our employees apply knowledge from one area of the company to problems and opportunities that arise in another. } \\
\text { Structural capital (Costa et al., 2014) }\end{array}$ \\
\hline STC1 & $\begin{array}{l}\text { There is a new product ideas scheme in place, and employees are encouraged to participate (for instance through economic } \\
\text { incentives) }\end{array}$ \\
\hline STC2 & Entrepreneurs and innovative project leaders are encouraged and rewarded, with no punishment for failures \\
\hline STC3 & Employees have autonomy and resources to develop their creativity through informal and parallel projects \\
\hline STC4 & The characteristics of project teams are a very important feature of the product innovation process \\
\hline STC5 & There is a plan to identify/acquire the skills that are necessary to achieve product innovation goals \\
\hline STC6 & Top management provides clear support, autonomy and authority to the people involved in product innovation projects \\
\hline STC7 & Innovation metrics represent an explicit and important part of top management's performance evaluation \\
\hline STC8 & Top management is strongly committed to the product innovation process \\
\hline STC9 & There is a system to manage NPD projects \\
\hline STC10 & The role of innovation in achieving the firm's strategic goals is clearly defined \\
\hline STC11 & There is a well-organized NPD process \\
\hline STC12 & $\begin{array}{l}\text { The areas of strategic focus on which to concentrate the product innovation efforts are clearly identified } \\
\boldsymbol{P A C A P} \text { (Engelman et al., 2017) } \\
\text { Acquisition }\end{array}$ \\
\hline ACQ1 & The search for relevant information concerning our industry is every-day business in our company. \\
\hline ACQ2 & Our management motivates the employees to use information sources within our industry. \\
\hline ACQ3 & Our management expects that the employees deal with information beyond our industry. \\
\hline & Assimilation \\
\hline ASS1 & In our company ideas and concepts are communicated cross-departmental. \\
\hline ASS2 & Our management emphasizes cross-departmental support to solve problems. \\
\hline ASS3 & In our company there is a quick information flow. \\
\hline ASS4 & $\begin{array}{l}\text { Our management demands periodical cross-departmental meetings to interchange new developments, problems, and achieve- } \\
\text { ments. } \\
\text { RACAP (Engelman et al., 2017) } \\
\text { Transformation }\end{array}$ \\
\hline TRF1 & Our employees have the ability to structure and to use collected knowledge. \\
\hline TRF2 & Our employees are used to absorb new knowledge as well as to prepare it for further purposes and to make it available. \\
\hline TRF3 & Our employees successfully link existing knowledge with new insights. \\
\hline TRF4 & $\begin{array}{l}\text { Our employees are able to apply new knowledge in their practical work. } \\
\text { Exploitation }\end{array}$ \\
\hline EXP1 & Our management supports the development of prototypes. \\
\hline EXP2 & Our company regularly reconsiders technologies and adapts them according to new knowledge. \\
\hline EXP3 & Our company has the ability to work more effectively by adopting new technologies. \\
\hline & $\begin{array}{l}\text { Cultural Intelligence (Ang et al., 2007; Gölgeci et al., 2016) } \\
\text { Metacognitive Intelligence }\end{array}$ \\
\hline MET1 & I am conscious of the cultural knowledge I use when interacting with people with different cultural backgrounds. \\
\hline MET2 & I adjust my cultural knowledge as I interact with people from a culture that is unfamiliar to me \\
\hline MET3 & I am conscious of the cultural knowledge I apply to cross-cultural interactions. \\
\hline & Cognitive Intelligence \\
\hline COG1 & I know the legal and economic systems of other cultures. \\
\hline COG2 & I know the rules (e.g. vocabulary, grammar) of other languages. \\
\hline COG3 & I know the cultural values and religious beliefs of other cultures. \\
\hline COG4 & $\begin{array}{l}\text { I know the rules for expressing nonverbal behaviors in other cultures. } \\
\text { Motivational Intelligence }\end{array}$ \\
\hline MOT1 & I am confident that I can socialize with locals in a culture that is unfamiliar to me. \\
\hline MOT2 & I am sure I can deal with the stresses of adjusting to a culture that is new to me. \\
\hline МОТ3 & I am confident that I can get accustomed to the shopping conditions in a different culture. \\
\hline & Behavioral Intelligence \\
\hline BEH1 & I change my verbal behavior (e.g. accent, tone) when a cross-cultural interaction requires it. \\
\hline $\mathrm{BEH} 2$ & I vary the rate of my speaking when a cross-cultural situation requires it. \\
\hline $\mathrm{BEH} 3$ & I alter my facial expressions when a cross-cultural interaction requires it \\
\hline
\end{tabular}

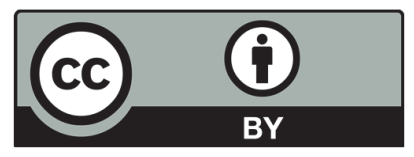

(C) 2021 by the authors; licensee Growing Science, Canada. This is an open access article distributed under the terms and conditions of the Creative Commons Attribution (CC-BY) license (http://creativecommons.org/licenses/by/4.0/). 